\title{
Down-Klinefelter syndrome $(48, X X Y,+21)$ in a Child with Congenital Heart Disease: Case Report and Literature Review
}

\author{
Zheng Shen, Chao Chun Zou, Shi Qiang Shang and Ke Wen Jiang
}

\begin{abstract}
Congenital heart disease (CHD) is extremely rarely reported in 48, XYY, +21 karyotype. Herein, we reported one case of $48, \mathrm{XYY},+21$ karyotype with $\mathrm{CHD}$ and reviewed the available literature. The phenotypic characteristics of the 4-month-old child showed the presence of features typical of mongoloid slant. X-ray detection showed the form of heart was corpulent and the bilateral mediastinum was broad. Doppler echocardiogram detection showed atrial septal and ventricular septal defects with patent ductus arteriosus, pulmonary hypertension and mild tricuspid regurgitation. Including this case, 63 cases of 48, XYY, +21 chromosome pattern have been reported. However, only 9 cases have CHD.
\end{abstract}

Key words: Down-Klinefelter syndrome, 48,XXY,+21, congenital heart disease

(Intern Med 51: 1371-1374, 2012)

(DOI: 10.2169/internalmedicine.51.7097)

\section{Introduction}

Down syndrome (trisomy 21, DS) is the most common chromosomal disorder in humans with an incidence of one in 770 live births (1). On the other hand, Klinefelter syndrome (KS), in which there is one extra $\mathrm{X}$ chromosome resulting in the karyotype of $47, \mathrm{XXY}(2)$, is also the most common disorder of sex chromosomes in humans, with prevalence of one in 500 males. The existence of two chromosomal abnormalities in the same individual is a relatively very rare phenomenon. Double trisomy (DT) leading to trisomy and/or monosomy of two different chromosomes arises because of two meiotic non-disjunctional events. Both these aneuploidies could have the same or different parental origin. The coincidence rate of both DS and KS in the same individual is about $0.098 \%$ in newborn (3). Many cases of DT of XXY and trisomy 21 have been published since the first reported by Ford et al. (4) However, to our knowledge, only 8 cases of $48, \mathrm{XXY},+21$ chromosome pattern with congenital Heart Disease (CHD) were reported previously with limited information (5-12).
Herein, we report a case of 4-month-old boy who exhibited $48, \mathrm{XXY},+21$ karyotype with CHD and review the pertinent literature to highlight the clinical features, diagnosis and management of this rare event.

\section{Case Report}

A 4-month-old child, the second-born of the parents, was admitted to our unit because of low appetite, small appearance and a weak cry. He was born at 38 weeks' gestation at home via normal spontaneous vaginal delivery following an uncomplicated pregnancy. The boy was gravida 2, para 2, and born without asphyxia history. His birth weight was about $2.6 \mathrm{~kg}$. His mother was 30 years old and did not use alcohol, drugs, or any medications during the pregnancy. His father was 32 years old and suffered from hyperthyroidism.

Upon physical examination, the child was $52 \mathrm{~cm}$ in height, $3.6 \mathrm{~kg}$ in weight and $34.5 \mathrm{~cm}$ in head circumference. Anterior and posterior fontanelles were patent and cranial sutures slightly separated. The genitalia were those of a normal, immature male. Generalized hypotonia was noted. No webbing of neck, multi nevus or lymphoedema was found.

Department of Pediatrics, the Children's Hospital of Zhejiang University School of Medicine and Zhejiang Key Laboratory for Diagnosis and Therapy of Neonatal Diseases, China

Received for publication January 20, 2012; Accepted for publication February 15, 2012

Correspondence to Dr. Ke Wen Jiang, kewenjiang@gmail.com 


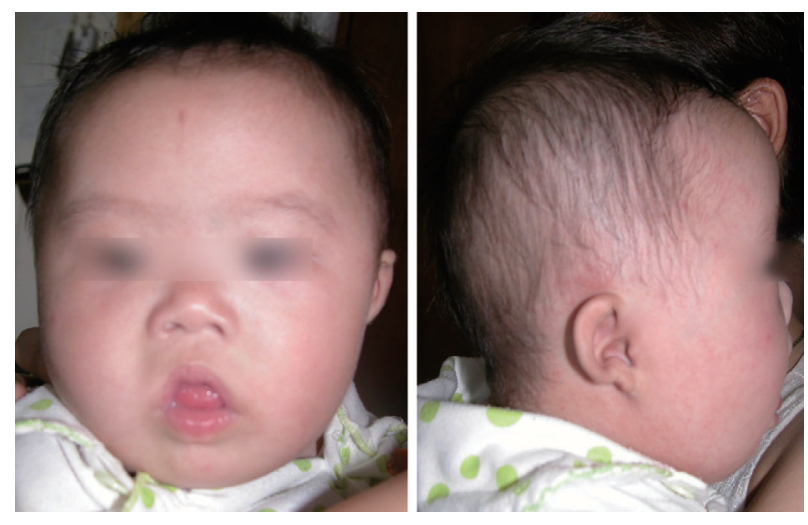

Figure 1. View of the face of the child with karyotype $48, X X Y,+21$, reveals signs of Down syndrome.

However, the phenotypic characteristics of the child showed the presence of features typical of mongoloid slant, including brachycephaly, flat facial profile, flat nasal bridge, short thick neck, hypertelorism, simian crease, slanted palpebral fissures, slightly low-set ears, flattened against the head, sandal gap sign, macrognathia, high palate, low hair line, and micropenis (Fig. 1).

The TORCH-IgG test showed positive for human cytomegalovirus and herpes simplex virus. The DNA test of Gram-negative bacteria was positive. Chest X-ray showed that the form of heart was corpulent and the bilateral mediastinum was broad, as observed in detection. The Doppler echocardiogram detection showed large atrial septal defect (secundum $0.55 \mathrm{~cm})$ and ventricular septal defect $(0.65 \mathrm{~cm})$ with patent ductus arteriosus $(0.3 \mathrm{~cm})$, pulmonary hypertension and mild tricuspid regurgitation (Fig. 2). The neurological exam was normal and the aural, ocular, nasal, thoracic and pulmonary exam all showed normal results. However, the dermal exam showed scattered eczema. Laboratory test results for liver and kidney function were all within normal limits or negative.

Cytogenetic study from both peripheral blood cultures revealed a complement of 48 chromosomes with two extra chromosomes in the $\mathrm{G}$ group. The karyotype was 48,XYY, +21 (Fig. 3). Two Y chromosomes were readily recognized on morphological criteria, and the other extra G group chromosomes was presumed to be 21. All metaphases were found to have the same pattern and no mosaicism was detected. The karyotypes of the parents were normal.

\section{Discussion}

Aneuploidy is defined as an abnormal number of chromosomes. It can involve both autosomal (chromosome 13, 18 or 21) and sex chromosomes and each may manifest either as a monosomy or trisomy or even tetra- or pentasomy. Theoretically, $50 \%$ of XXY cases could arise from an error in paternal meiosis Iand the remaining in maternal meiosis I or II. On the other hand, trisomy 21 can originate in either of the divisions in both parents. Abnormal separation of chromosomes may occur in older individuals because of dysfunction of structures related to chromosome separation, such as the spindle apparatus and kinetochore.

The first patient with double trisomy combining Down syndrome and Klinefelter syndrome was described by Ford et al. (4) in 1959. Since then, about 62 cases have been reported in the literature, which include 36 cases with known parental ages, Kovaleva and Mutton (3) found that the risk for $48, \mathrm{XXY},+21$ was age dependent, with a mean maternal age of 33 years and a mean paternal age of 38 years. However, in this report, the parents of the case were relatively young, 30-year-old mother and 32-year-old father. Hence, we thought that it is also necessary to pay attention to this rare event in younger parents.

As sexual development in humans primarily depends on the presence of the Y chromosome, the 48,XXY,+21 karyotype usually presents male phenotype. Most of the published cases of $48, \mathrm{XXY},+21$ showed typical features of Down syndrome alone. But the characteristic features of Klinefelter syndrome are not apparent until the post-pubertal stage. According to the Down-Klinefelter case reports, neonates and infants younger than 10 months show few or no clinical appearance of Klinefelter syndrome. These characteristics begin developing with the child ages. Our neonate had features of trisomy 21, but not Klinefelter syndrome, which is consistent with other case reports.

Adult patients with isolated Klinefelter syndrome may occasionally suffer from mitral valve prolapse. However, an obvious relationship between this syndrome and CHD has not been documented, with exception of several case reports (13). In contrast, Down syndrome alone is well known for cardiac anomalies, occurring in $40 \%$ to $50 \%$ of patients (14). Freeman et al. (15) reported a $44 \%$ incidence of CHD in a group of 227 infants with DS, of which $45 \%$ were atrioventricular, $35 \%$ were ventricular and $8 \%$ had an isolated atrial septal defect. The remaining $12 \%$ had other anomalies. To the best of our knowledge, including this case, 63 cases of double trisomy with 48 , XXY, +21 chromosome pattern were reported, but only 9 cases have congenital heart disease (Table 1). The incidence and spectrum of cardiovascular anomalies in children born with DownKlinefelter syndrome is not known. Prior to our case only 8 case reports on CHD in these patients were published.

In conclusion, Down-Klinefelter syndrome is a rare occurrence. It presents trisomy 21 characteristics early in life and Klinefelter syndrome features after 10 months of age. Pediatric cardiologists are familiar with screening of babies with DS for CHD. However, in children diagnosed with $\mathrm{KS}$, a CHD has only rarely been reported. Reports on CHD with double aneuploidy of DS and KS are scarce with the incidence of 9/63. We report on a child with DS and KS associated with a large ventricular septal defect $(0.65 \mathrm{~cm})$ and an atrial septal defect $(0.55 \mathrm{~cm})$ with patent ductus arteriosus $(0.3 \mathrm{~cm})$, pulmonary hypertension and mild tricuspid regurgitation. 

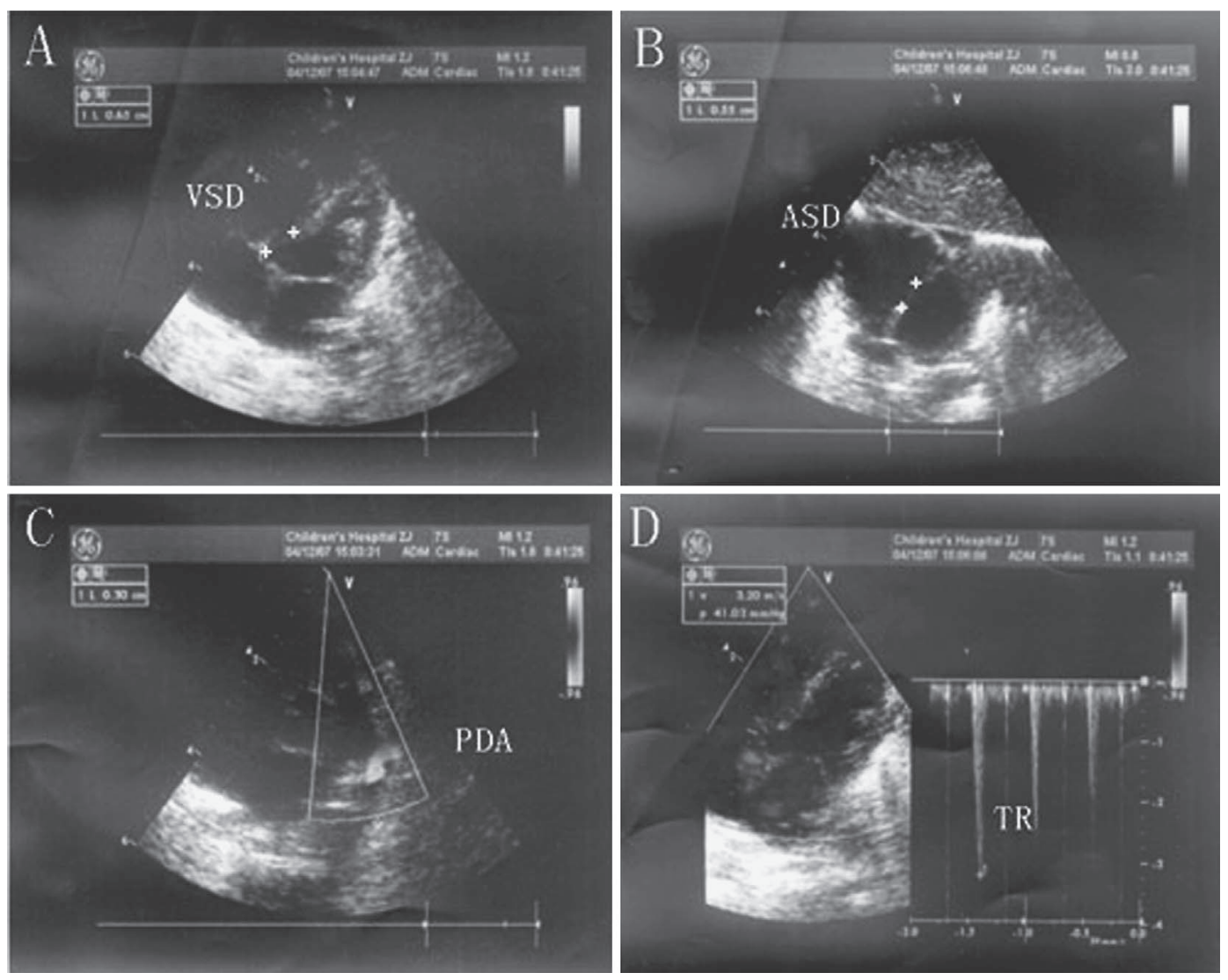

Figure 2. Doppler sonogram showing (A) a large ventricular septal defect $(0.65 \mathrm{~cm})$ and $(\mathrm{B})$ a atrial septal defect $(0.55 \mathrm{~cm})$ with $(\mathrm{C})$ patent ductus arteriosus $(0.3 \mathrm{~cm}),(\mathrm{D})$ pulmonary hypertension and mild tricuspid regurgitation.

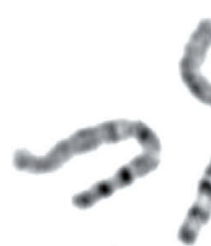

1
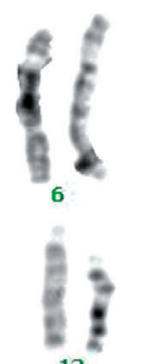

13

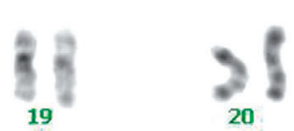

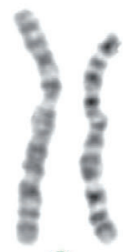
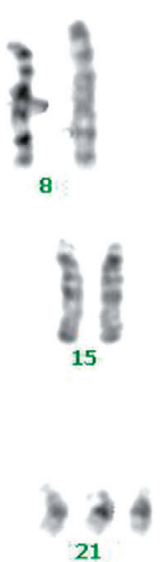

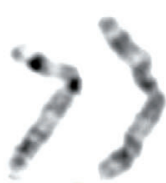

3

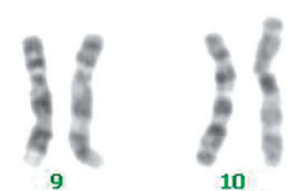

$\sum_{16}$

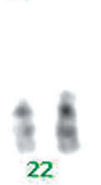

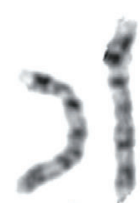

4
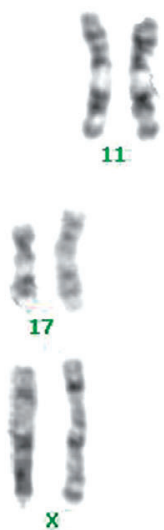

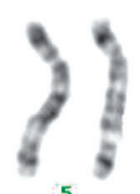

5
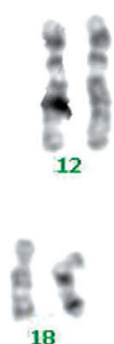

18

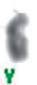

Figure 3. GTG-banded karyotype of this patient showing double aneuploidy $48, \mathrm{XXY},+21$.

The authors state that they have no Conflict of Interest (COI).

\section{Acknowledgement}

We want to thank the patient's parents for allowing us to use the data. And this work is supported by the Natural Science Foundation of Zhejiang Province (Y2100053) and the Zhejiang Traditional Chinese Medicine Foundation (2010B500840). 
Table 1. Phenotypes of 48,XXY,+21 with CHD Cases Described in Case Reports

\begin{tabular}{|c|c|c|c|c|}
\hline Case/Ref & Age/gender & Characteristics of DS & Characteristics of KS & Congential heart disease \\
\hline Our case & $4 \mathrm{~m} / \mathrm{Male}$ & $\begin{array}{l}\text { brachycephaly, flat facial profile, flat nasal bridge, short thick neck, hypertelorism, simian } \\
\text { crease, slanted palpebral fissures, slightly low-set ears, flattened against the head, sandal gap } \\
\text { sign, macrognathia, high palate, low hair line, micropenis }\end{array}$ & None & $\begin{array}{l}\text { large atrial septal defect and ventricular } \\
\text { septal defect with patent ductus } \\
\text { arteriosus, pulmonary hypertension and } \\
\text { mild tricuspid regurgitation. }\end{array}$ \\
\hline Hustinx et al.[5] & $\begin{array}{l}7 \mathrm{~m} \text { twin boys } \\
\text { /Male }\end{array}$ & $\begin{array}{l}\text { Brachycephaly, epicanthus, fissured tongue, short, thick fingers and toes, mongoloid palm } \\
\text { prints and hypermobillity of the joints }\end{array}$ & None & $\begin{array}{l}\text { One: cardiac anomalies } \\
\text { The other: an open ductus Botalli and a } \\
\text { septum anomaly }\end{array}$ \\
\hline Hecht et al.[7] & $8 \mathrm{y} /$ Male & $\begin{array}{l}\text { Mental retardation (I.Q. 28), muscular hypotonia, growth retardation, brachycephaly, small } \\
\text { down-folded pinnae, epicanthal folds, Brushfield spots, upward slant to the palpebral fissures, } \\
\text { slight nystagmus, furrowed tongue, umbilical hernia, sandal gap, hypoplasia of the middle } \\
\text { phalanx of the } 5 \text { th digit, absence of right } 12 \text { th rib, spina bifida occulta (S1-S3) }\end{array}$ & $\begin{array}{l}\text { Hypospadias, infantile } \\
\text { testes with uniformly } \\
\text { small tubules devoid of } \\
\text { spermatogonia. }\end{array}$ & $\begin{array}{l}\text { Mild aortic stenosis with possible } \\
\text { coexistent pulmonary stenosis }\end{array}$ \\
\hline $\begin{array}{l}\text { Erdtmann et } \\
\text { al.[8] }\end{array}$ & $2 \mathrm{y} / \mathrm{Male}$ & $\begin{array}{l}\text { Loose skin, hypotrophic and slightly hypotonic muscles, brachycephalic head, asymmetrical } \\
\text { face, bilateral epicanthus and small eyes, short neck with pterygium colli, hypoplasic nasal } \\
\text { bone, implanted low and malformed ears, narrow palatal arch, cone-shaped incisors and slight } \\
\text { micrognathia }\end{array}$ & None & $\begin{array}{l}\text { A surcharge of the right auricle and } \\
\text { ventricle compatible }\end{array}$ \\
\hline Efinski et al.[9] & $15 \mathrm{y} /$ Male & $\begin{array}{l}\text { Eyes slanted downward and inward, ocular hypertelorism, low-set malformed ears, saddle } \\
\text { nose, fissured large tongue, a narrow palatal arch, short neck, narrow shoulders, small penis, } \\
\text { and hypotony muscular and weak tendon reflexes }\end{array}$ & $\begin{array}{l}\text { An antisocial behaviour } \\
\text { and epilepsy seizures }\end{array}$ & $\begin{array}{l}\text { A systolic murmur, and generalized } \\
\text { cyanosis developed during exercise }\end{array}$ \\
\hline Akbas et al.[10] & $2 \mathrm{y} /$ Male & $\begin{array}{l}\text { Flat face, flat nasal bridge, hypertelorism, epicanthal folds, macrognathia, high palate, extra } \\
\text { skin on the neck, low hair line, simian crease, micropenis, bilateral cryptorchidism }\end{array}$ & None & $\begin{array}{l}\text { Atrioventricular septal defect with } \\
\text { pulmonary stenosis }\end{array}$ \\
\hline Gerretsen et al.[11] & $14 \mathrm{~m} / \mathrm{Male}$ & Not be described & None & $\begin{array}{l}\text { A small atrial septal defect } \\
\text { (secundum type) and a double aortic } \\
\text { arch }\end{array}$ \\
\hline Jeanty et al.[12] & Fetus & Low nasal bridge, short thick neck, oblique palpebral fissures & None & Atrioventricular canal defect \\
\hline
\end{tabular}

\section{References}

1. Iliopoulos D, Poultsides G, Peristeri V, Kouri G, Andreou A, Voyiatzis N. Double trisomy $(48, \mathrm{XXY},+21)$ in monozygotic twins: case report and review of the literature. Ann Genet 47: 95-98, 2004.

2. Visootsak J, Graham JM Jr. Klinefelter syndrome and other sex chromosomal aneuploidies. Orphanet J Rare Dis 1: 42, 2006.

3. Kovaleva NV, Mutton DE. Epidemiology of double aneuploidies involving chromosome 21 and the sex chromosomes. Am J Med Genet A 134A: 24-32, 2005.

4. Ford CE, Jones KW, Miller OJ, et al. The chromosomes in a patient showing both mongolism and the Klinefelter syndrome. Lancet 1: 709-710, 1959.

5. Hustinx TW, Eberle P, Geerts SJ, Ten B, Woltring LM. Mongoloid twins with 48 chromosomes (AA plus A21XXY). Ann Hum Genet 25: 111-115, 1961.

6. De Grouchy J, Emerit I, DE Gennes JL, Vernant P. Klinefelter's syndrome in a 6-year-old trisomy-21 boy. Presse Med 73: 1209$1212,1965$.

7. Hecht F, Nievaard JE, Duncanson N, et al. Double aneuploidy: the frequency of XXY in males with Down's syndrome. Am J Hum Genet 21: 352-359, 1969.

8. Erdtmann B, de Freitas AA, de Souza RP, Salzano FM. Klinefelter's syndrome and G trisomy. J Med Genet 8: 364-368, 1971.
9. Efinski D, Duma H, Apostolovski B, Sofijanov N, Ristevski B, Darkovski S. Klinefelter's and Down's syndrome in an adolescent with abnormal EEG. Clin Genet 5: 81-85, 1974.

10. Akbas E, Soylemez F, Savasoglu K, Halliogluand O, Balci S. A male case with double aneuploidy $(48, \mathrm{XXY},+21)$. Genet Couns 19: 59-63, 2008.

11. Gerretsen MF, Peelen W, Rammeloo LA, Koolbergen DR, Hruda J. Double aortic arch with double aneuploidy-rare anomaly in combined Down and Klinefelter syndrome. Eur J Pediatr 168: 1479-1481, 2009.

12. Jeanty C, Turner C. Prenatal diagnosis of double aneuploidy, 48, $\mathrm{XXY},+21$, and Review of the Literature. J Ultrasound Med 28: 673-681, 2009.

13. Rosenthal A. Cardiovascular malformations in Klinefelter's syndrome: report of three cases. J Pediatr 80: 471-473, 1972.

14. Pierpont ME, Basson CT, Benson DW Jr, et al. American Heart Association Congenital Cardiac Defects Committee, Council on Cardiovascular Disease in the Young., Genetic basis for congenital heart defects: current knowledge: a scientific statement from the American Heart Association Congenital Cardiac Defects Committee, Council on Cardiovascular Disease in the Young: endorsed by the American Academy of Pediatrics. Circulation 115: 3015-3038, 2007.

15. Freeman SB, Taft LF, Dooley KJ, et al. Population-based study of congenital heart defects in Down syndrome. Am J Med Genet 80: 213-217, 1998

(C) 2012 The Japanese Society of Internal Medicine http://www.naika.or.jp/imindex.html 